Widayat, D. • C.O. Purba

\title{
Produktivitas tanaman dan kehilangan hasil tanaman padi (Oryza sativa L.) kultivar Ciherang pada kombinasi jarak tanam dengan frekuensi penyiangan berbeda
}

\section{Productivity and lossing yield of Ciherang cultivar rice plant (Oryza sativa $L_{\text {.) }}$ on plant spacing combination and different weeding frequency}

Diterima : Januari 2015/Disetujui : Februari 2015 / Dipublikasikan : Maret 2015

CDepartment of Crop Science, Padjadjaran University

\begin{abstract}
The purpose of this study was to determine the effect of the combination of plant spacing and weeding frequency different on the productivity and lost yield of lowland rice cultivars Ciherang. The experiment was conducted in Studio Training Research and Development (SPLPP) Faculty of Agriculture, University of Padjadjaran Ciparay units from November 2010 to February 2011. The experimental design was used a randomized block design (RBD) consists of twelve treatments, with three replications. The treatments used were as follows: A (spacing $25 \times 25 \mathrm{~cm}$ with no weeding), B (spacing of $25 \times 25 \mathrm{~cm}$ with one time weeding), C (spacing of $25 \times 25 \mathrm{~cm}$ with, twice time weeding), D (spacing of $25 \times 25 \mathrm{~cm}$ with three times weeding), E (spacing of $28 \times 28 \mathrm{~cm}$ with no weeding), $F$ (spacing of $28 \times 28 \mathrm{~cm}$ with one time weeding), G (Spacing $28 \times 28 \mathrm{~cm}$ with twice time weeding), $\mathrm{H}$ (spacing of $28 \times 28 \mathrm{~cm}$ with three times weeding), I (spacing of $30 \times 30$ $\mathrm{cm}$ with no weeding), J (spacing of $30 \times 30 \mathrm{~cm}$ with one time weeding), $\mathrm{K}$ (spacing of $30 \times 30$ $\mathrm{cm}$ with twice time weeding), L (spacing of $30 \mathrm{x}$ $30 \mathrm{~cm}$ with three times weeding). The experimental results showed that with a spacing of 30 $x 30 \mathrm{~cm}$ with three times weeding will give the best results for the rice crop cultivars Ciherang and increase yields compared with plant spacing $25 \times 25 \mathrm{~cm}$ with three times weeding.
\end{abstract}

Keywords: Rice productivity · Lost yield .

\begin{tabular}{l}
\hline Dikomunikasikan oleh Fiky Yulianto W. \\
D. Widayat ${ }^{1}$ C.O. Purba ${ }^{2}$ \\
${ }^{1}$ Staf Akademik Fakultas Pertanian Unpad \\
${ }^{2}$ Mahasiswa Fakultas Pertanian Unpad \\
Jl. Raya Bandung - Sumedang Km. 21 Jatinangor \\
Korespondensi : widayatdedi@yahoo.com
\end{tabular}

Cultivars Ciherang · Plant spacing. Weeding frequency

Sari Tujuan penelitian ini adalah untuk mengetahui pengaruh kombinasi jarak tanam dan frekuensi penyiangan gulma yang berbeda terhadap produktivitas dan kehilangan hasil padi sawah kultivar Ciherang. Percobaan ini dilaksanakan di lahan sawah Sanggar Penelitian Latihan dan Pengembangan Pertanian (SPLPP) Fakultas Pertanian Universitas Padjadjaran unit Ciparay dari bulan November 2010 sampai Februari 2011. Rancangan percobaan yang digunakan adalah Rancangan Acak Kelompok (RAK) terdiri dari dua belas perlakuan, dengan tiga kali ulangan. Adapun perlakuan yang digunakan adalah sebagai berikut : A (jarak tanam $25 \times 25 \mathrm{~cm}$ dengan tanpa penyiangan), B (jarak tanam $25 \times 25 \mathrm{~cm}$ dengan disiang satu kali), C (jarak tanam $25 \times 25 \mathrm{~cm}$ dengan, disiang dua kali), D (jarak tanam $25 \times 25 \mathrm{~cm}$ dengan disiang tiga kali), E (jarak tanam $28 \times 28 \mathrm{~cm}$ dengan tanpa penyiangan), F (jarak tanam $28 \times 28 \mathrm{~cm}$ dengan disiang satu kali), G (jarak tanam $28 \times 28 \mathrm{~cm}$ dengan disiang dua kali), $\mathrm{H}$ (jarak tanam $28 \times 28$ $\mathrm{cm}$ dengan disiang tiga kali), I (jarak tanam $30 \times 30$ $\mathrm{cm}$ dengan tanpa penyiangan), J (jarak tanam $30 \mathrm{x}$ $30 \mathrm{~cm}$ dengan disiang satu kali), $\mathrm{K}$ (jarak tanam 30 $x 30 \mathrm{~cm}$ dengan disiang dua kali), L (jarak tanam $30 \times 30 \mathrm{~cm}$ dengan disiang tiga kali). Hasil percobaan menunjukkan bahwa dengan jarak tanam $30 \times 30 \mathrm{~cm}$, disiang tiga kali akan memberikan hasil yang paling baik terhadap hasil panen padi kultivar Ciherang dan akan meningkatkan hasil panen dibanding dengan jarak tanam standar, yaitu $25 \mathrm{~cm} \times 25 \mathrm{~cm}$, disiang tiga kali. Kehilangan hasil tertinggi diperoleh pada perlakuan jarak tanam $30 \times 30 \mathrm{~cm}$ dengan tanpa penyiangan. 
Kata kunci : Produktivitas padi · Kehilangan hasil · Kultivar Ciherang · Jarak tanam · Prekuensi penyiangan

\section{Pendahuluan}

Padi (Oryza sativa L.) merupakan komoditas tanaman pangan yang sangat penting dan banyak diusahakan di Indonesia, karena menghasilkan bahan makanan pokok yang dikonsumsi sebagian besar penduduk Indonesia sebagai sumber karbohidrat.

Gulma pada pertanaman merupakan salah satu masalah penting karena dapat menurunkan produksi tanaman baik secara kuantitas maupun kualitas. Besarnya penurunan hasil akibat persaingan dengan gulma bagi berbagai tanaman budidaya berbeda tergantung pada daya saing masing-masing jenis tanaman. Kemampuan bersaing suatu spesies tanaman banyak ditentukan oleh ruang yang dapat dikuasai pada awal pertumbuhannya (Spitter dan Van der Bergh, 1982). Tanaman yang lambat menguasai ruang tumbuh menyebabkan gulma tumbuh lebih pesat sehingga kemampuan tanaman bersaing menurun jika tidak dilakukan pengendalian gulma secepatnya.

Madkar, dkk (1986), mengemukakan penanaman dengan jarak tanam yang sangat jarang memberikan kesempatan pada gulma untuk tumbuh secara leluasa, sebaliknya jarak tanam yang sempit pertumbuhan gulma tertekan tetapi memungkinkan tanaman budidaya memberikan hasil kurang baik dikarenakan terjadinya kompetisi di antara tanaman budidaya. Sebaiknya tanaman ditanam pada jarak yang optimal.

Untuk mendapatkan produktivitas yang tinggi terhadap suatu tanaman budidaya diharapkan pengaruh jarak tanam dapat memberikan hasil yang optimal dan pengendalian gulma melalui penyiangan yang rendah. Sehingga dengan demikian, dapat dicapai suatu produksi atau hasil yang optimal dan tidak menimbulkan kerugian baik dari segi hasil dan segi biaya dalam pengolahan dan pengendalian gulma tersebut.

\section{Bahan dan Metode}

Penelitian dilaksanakan di lahan sawah Sanggar Penelitian Latihan dan Pengembangan Pertanian (SPLPP) Fakultas Pertanian Universitas Padjajaran
Unit Ciparay. Ketinggian tempat penelitian sekitar 600 - $700 \mathrm{~m}$ di atas permukaan laut dengan jenis tanah Inceptisol dan tipe curah hujan $\mathrm{C}$ atau agak basah menurut kriteria dari Schmidt Forguson. Penelitian dilakukan dari bulan November 2010 sampai dengan bulan Februari 2011.

Penelitian menggunakan metode eksperimen dengan Rancangan Acak Kelompok (RAK) yang terdiri dari dua belas perlakuan dan tiga kali pengulangan sehingga terdapat 36 petak percobaan.

Perlakuan-perlakuan tersebut adalah sebagai berikut: (A) Jarak tanam $25 \times 25 \mathrm{~cm}$, dengan tanpa penyiangan; (B) Jarak tanam $25 \times 25 \mathrm{~cm}$ dengan penyiangan satu kali; (C) Jarak tanam 25 x $25 \mathrm{~cm}$ dengan penyiangan dua kali; (D) Jarak tanam $25 \times 25 \mathrm{~cm}$ dengan penyiangan tiga kali; (E) Jarak tanam $28 \times 28 \mathrm{~cm}$ dengan tanpa penyiangan; (F) Jarak tanam $28 \times 28 \mathrm{~cm}$ dengan penyiangan satu kali; (G) Jarak tanam $28 \times 28$ $\mathrm{cm}$ dengan penyiangan dua kali; (H) Jarak tanam $28 \times 28 \mathrm{~cm}$ dengan penyiangan tiga kali;

(I) Jarak tanam $30 \times 30 \mathrm{~cm}$ dengan tanpa penyiangan; (J) Jarak tanam $30 \times 30 \mathrm{~cm}$ dengan penyiangan satu kali; (K) Jarak tanam $30 \times 30 \mathrm{~cm}$ dengan penyiangan dua kali; (L) Jarak tanam 30 x $30 \mathrm{~cm}$ dengan penyiangan tiga kali.

Variabel pengamatan utama dilakukan terhadap : Bobot kering gulma per golongan dan bobot kering gulma total, komponen pertumbuhan dan hasil tanaman padi yang meliputi : tinggi tanaman, jumlah anakan peproduktif, bobot kering tanaman,jumlah malai per rumpun, bobot butir per rumpun, bobot 1000 butir dan hasil gabah per petak. Pengamatan penunjang dilakukan terhadap Jenis-jenis gulma yang terdapat sebelum percobaan, serangan hama dan penyakit selama percobaan, dan persentase penutupan gulma.

\section{Hasil dan Pembahasan}

Bobot Kering Gulma Berdaun Lebar. Hasil analisis terhadap bobot berat kering gulma golongan daun lebar terlihat bahwa pada awal pengamatan (2 MST) semua perlakuan tidak menunjukkan perbedaan yang nyata, namun seiring dengan bertambahnya umur tanaman, bobot kering gulma pada semua perlakuan jarak tanam dan tidak disiangi lebih tinggi dan berbeda nyata dengan perlakuan semua jarak tanam yang disiangi (Tabel 1).

Widayat dan Purba: Produktivitas tanaman dan kehilangan hasil tanaman padi (Oryza sativa L.)

kultivar Ciherang pada kombinasi jarak tanam dengan frekuensi penyiangan berbeda 
Hal tersebut terjadi karena lama hidup dari gulma pada perlakuan yang ada, berbeda-beda sesuai dengan saat penyiangan. Hal ini sesuai dengan pendapat Christin Juliana (2010) yang menyatakan bahwa semakin lama gulma tumbuh bersama tanaman pokok, semakin besar persaingannya, pertumbuhan tanaman pokok semakin terhambat, dan hasilnya semakin menurun.

Tabel 1. Pengaruh Perlakuan terhadap Bobot Kering Gulma Berdaun Lebar.

\begin{tabular}{ccccc}
\hline Perlakuan & \multicolumn{4}{c}{$\begin{array}{c}\text { Rata-rata Bobot Kering Gulma } \\
\text { Berdaun Lebar (g) pada Umur }\end{array}$} \\
\cline { 2 - 5 } & 2 MST & 4 MST & 6 MST & 8 MST \\
\hline A & $2,74 \mathrm{a}$ & $7,13 \mathrm{~b}$ & $9,87 \mathrm{~b}$ & $10,61 \mathrm{de}$ \\
$\mathrm{B}$ & $1,69 \mathrm{a}$ & $0,66 \mathrm{a}$ & $1,30 \mathrm{a}$ & $2,54 \mathrm{ab}$ \\
$\mathrm{C}$ & $2,68 \mathrm{a}$ & $1,07 \mathrm{a}$ & $2,11 \mathrm{a}$ & $3,33 \mathrm{ab}$ \\
$\mathrm{D}$ & $2,40 \mathrm{a}$ & $0,96 \mathrm{a}$ & $2,30 \mathrm{a}$ & $2,41 \mathrm{a}$ \\
E & $2,40 \mathrm{a}$ & $5,53 \mathrm{~b}$ & $7,57 \mathrm{~b}$ & $9,93 \mathrm{de}$ \\
F & $3,12 \mathrm{a}$ & $1,56 \mathrm{a}$ & $2,99 \mathrm{a}$ & $5,73 \mathrm{bc}$ \\
G & $2,91 \mathrm{a}$ & $1,45 \mathrm{a}$ & $3,88 \mathrm{a}$ & $4,87 \mathrm{abc}$ \\
H & $2,22 \mathrm{a}$ & $1,10 \mathrm{a}$ & $1,16 \mathrm{a}$ & $2,21 \mathrm{a}$ \\
I & $2,38 \mathrm{a}$ & $6,11 \mathrm{~b}$ & $8,54 \mathrm{~b}$ & $11,80 \mathrm{e}$ \\
J & $3,22 \mathrm{a}$ & $1,93 \mathrm{a}$ & $3,81 \mathrm{a}$ & $7,57 \mathrm{~cd}$ \\
K & $1,91 \mathrm{a}$ & $1,14 \mathrm{a}$ & $1,46 \mathrm{a}$ & $4,38 \mathrm{ab}$ \\
L & $2,41 \mathrm{a}$ & $1,44 \mathrm{a}$ & $3,04 \mathrm{a}$ & $1,75 \mathrm{a}$ \\
\hline \hline
\end{tabular}

Keterangan : Nilai rata-rata yang diikuti oleh huruf yang sama menunjukkan tidak berbeda nyata menurut uji Duncan pada taraf 5\%

Pada perlakuan semua jarak tanam dengan penyiangan tiga kali tidak terdapat perbedaan nyata bobot kering gulma pada semua umur pengamatan, hal ini dikarenakan frekuensi penyiangan yang paling optimal dilakukan, sehingga gulma tersebut hampir tidak ada.

Bobot Kering Gulma Rumput. Dari Tabel 2 dapat diketahui bahwa rata-rata bobot kering gulma rumput pada pengamatan 2 MST dan 4 MST tidak menunjukkan perbedaan nyata pada seluruh perlakuan. Hal ini dimungkinkan terjadi karena rendahnya gulma rumput yang tumbuh. Rendahnya gulma rumput yang tumbuh dapat disebabkan karena biji-biji gulma rumput masih dalam keadaan dorman pada awal fase vegetatif padi.

Pada pengamatan 6 MST dan 8 MST juga tidak terdapat perbedaan nyata pada setiap perlakuan yang berbeda. Hal ini juga dapat disebabkan karena sedikitnya jumlah gulma rumput yang tumbuh pada masa generatif, sehingga persaingan tanaman dengan gulma juga tidak begitu berarti.
Tabel 2. Pengaruh Perlakuan terhadap Bobot Kering Gulma Rumput.

\begin{tabular}{ccccc}
\hline \hline Perlakuan & \multicolumn{4}{c}{$\begin{array}{c}\text { Rata-rata Bobot Kering Gulma } \\
\text { Rumput (g) }\end{array}$} \\
\cline { 2 - 5 } & 2 MST & 4 MST & 6 MST & 8 MST \\
\hline A & $0,93 \mathrm{a}$ & $1,96 \mathrm{a}$ & $2,84 \mathrm{a}$ & $4,15 \mathrm{a}$ \\
B & $1,14 \mathrm{a}$ & $0,34 \mathrm{a}$ & $1,45 \mathrm{a}$ & $1,31 \mathrm{a}$ \\
C & $1,55 \mathrm{a}$ & $0,47 \mathrm{a}$ & $0,46 \mathrm{a}$ & $0,44 \mathrm{a}$ \\
D & $1,22 \mathrm{a}$ & $0,37 \mathrm{a}$ & $1,92 \mathrm{a}$ & $0,96 \mathrm{a}$ \\
E & $0,98 \mathrm{a}$ & $2,16 \mathrm{a}$ & $0,14 \mathrm{a}$ & $0,90 \mathrm{a}$ \\
F & $1,27 \mathrm{a}$ & $0,51 \mathrm{a}$ & $1,02 \mathrm{a}$ & $1,74 \mathrm{a}$ \\
G & $1,18 \mathrm{a}$ & $0,47 \mathrm{a}$ & $1,16 \mathrm{a}$ & $1,27 \mathrm{a}$ \\
H & $0,14 \mathrm{a}$ & $0,06 \mathrm{a}$ & $0,24 \mathrm{a}$ & $0,24 \mathrm{a}$ \\
I & $0,99 \mathrm{a}$ & $2,37 \mathrm{a}$ & $3,73 \mathrm{a}$ & $3,33 \mathrm{a}$ \\
J & $1,16 \mathrm{a}$ & $0,58 \mathrm{a}$ & $1,22 \mathrm{a}$ & $1,20 \mathrm{a}$ \\
K & $1,18 \mathrm{a}$ & $0,59 \mathrm{a}$ & $0,83 \mathrm{a}$ & $0,95 \mathrm{a}$ \\
L & $0,56 \mathrm{a}$ & $0,28 \mathrm{a}$ & $1,54 \mathrm{a}$ & $1,41 \mathrm{a}$ \\
\hline \hline
\end{tabular}

Keterangan : Nilai rata-rata yang diikuti oleh huruf yang sama menunjukkan tidak berbeda nyata menurut uji Duncan pada taraf 5\%

Bobot Kering Gulma Teki. Dari Tabel 3 dapat diketahui bahwa rata-rata bobot kering gulma teki pada pengamatan 2 MST dan 4 MST tidak menunjukkan perbedaan nyata pada seluruh perlakuan. Hal ini dimungkinkan terjadi karena rendahnya gulma teki yang tumbuh di area percobaan.

Tabel 3. Pengaruh Perlakuan terhadap Bobot Kering Gulma Teki.

\begin{tabular}{ccccc}
\hline \hline Perlakuan & \multicolumn{4}{c}{ Rata-Rata Bobot Kering Gulma Teki } \\
& \multicolumn{4}{c}{ (g) pada Umur } \\
\cline { 2 - 5 } & 2 MST & 4 MST & 6 MST & 8 MST \\
\hline A & $0,17 \mathrm{a}$ & $0,52 \mathrm{a}$ & $0,87 \mathrm{~h}$ & $1,30 \mathrm{~h}$ \\
$\mathrm{~B}$ & $0,18 \mathrm{a}$ & $0,18 \mathrm{a}$ & $0,36 \mathrm{~g}$ & $0,70 \mathrm{~g}$ \\
C & $0,13 \mathrm{a}$ & $0,15 \mathrm{a}$ & $0,00 \mathrm{a}$ & $0,00 \mathrm{a}$ \\
D & $0,54 \mathrm{a}$ & $0,32 \mathrm{a}$ & $0,00 \mathrm{a}$ & $0,00 \mathrm{a}$ \\
E & $0,09 \mathrm{a}$ & $0,99 \mathrm{a}$ & $1,44 \mathrm{i}$ & $2,60 \mathrm{i}$ \\
F & $0,24 \mathrm{a}$ & $0,14 \mathrm{a}$ & $0,21 \mathrm{e}$ & $0,30 \mathrm{e}$ \\
G & $0,19 \mathrm{a}$ & $0,11 \mathrm{a}$ & $0,00 \mathrm{a}$ & $0,00 \mathrm{a}$ \\
H & $0,26 \mathrm{a}$ & $0,16 \mathrm{a}$ & $0,15 \mathrm{c}$ & $0,20 \mathrm{c}$ \\
I & $0,15 \mathrm{a}$ & $0,47 \mathrm{a}$ & $1,66 \mathrm{j}$ & $2,50 \mathrm{j}$ \\
J & $0,19 \mathrm{a}$ & $0,11 \mathrm{a}$ & $0,24 \mathrm{f}$ & $0,50 \mathrm{f}$ \\
K & $0,60 \mathrm{a}$ & $0,36 \mathrm{a}$ & $0,10 \mathrm{~b}$ & $0,10 \mathrm{~b}$ \\
L & $0,15 \mathrm{a}$ & $0,09 \mathrm{a}$ & $0,19 \mathrm{~d}$ & $0,40 \mathrm{~d}$ \\
\hline \hline
\end{tabular}

$\overline{\text { Keterangan : Nilai rata-rata yang diikuti oleh huruf }}$ yang sama menunjukkan tidak berbeda nyata menurut uji Duncan pada taraf 5\%

Pada pengamatan 6 MST dan 8 MST setiap perlakuan memberikan pengaruh yang sama. Hal ini dikarenakan gulma teki lebih banyak tumbuh pada umur tanaman tersebut. Seiring 
dengan bertambahnya umur tanaman padi, daun tanaman semakin tinggi dan membesar sehingga terjadi efek naungan, sedangkan gulma golongan teki merupakan salah satu jenis tumbuhan yang tidak tahan terhadap naungan (Nasution, 1986).

Bobot Kering Gulma Total. Pada umur 2 MST bobot kering gulma total pada setiap perlakuan tidak berbeda nyata pada setiap perlakuan (Tabel 4). Hal ini dikarenakan persai-ngan antara gulma dengan tanaman masih dapat bersaing untuk mendapatkan hara. Lalu pada umur 4 MST, pada petak A, E, dan I, yaitu dengan perlakuan tanpa penyiangan bobot gulma total lebih banyak. Hal ini dikarenakan gulma tumbuh lebih banyak. Pada pengamatan 6 MST dan 8 MST, jumlah bobot gulma total menunjukkan masih lebih tinggi pada perlakuan dengan tanpa penyiangan, dibanding dengan perlakuan lainnya. Relatif sedikitnya gulma yang tumbuh menjadikan bobot gulma total yang rendah. Selain oleh efektifnya penyiangan hal ini juga dapat ditunjang dari tingginya kemampuan kompetisi tanaman padi terhadap gulma sehingga gulma tidak dapat tumbuh optimal karena tidak mampu bersaing memperebutkan faktor tumbuh dengan tanaman padi. Tertekannya pertumbuhan gulma tersebut, memberikan pengaruh yang baik terhadap pertumbuhan dan hasil produksi tanaman padi. Unsur hara, air, cahaya, udara dan ruang tumbuh yang tersedia dapat dimanfaatkan seoptimal mungkin oleh tanaman padi.

Tabel 4. Pengaruh Perlakuan terhadap Bobot Kering Gulma Total.

\begin{tabular}{ccccc}
\hline \hline Perlakuan & \multicolumn{4}{c}{ Rata-Rata Bobot Kering Gulma Total } \\
& \multicolumn{4}{c}{$(\mathrm{g})$ pada Umur } \\
\cline { 2 - 5 } & $2 \mathrm{MST}$ & $4 \mathrm{MST}$ & $6 \mathrm{MST}$ & $8 \mathrm{MST}$ \\
\hline $\mathrm{A}$ & $3,84 \mathrm{a}$ & $9,62 \mathrm{~b}$ & $13,60 \mathrm{~d}$ & $16,05 \mathrm{c}$ \\
$\mathrm{B}$ & $2,99 \mathrm{a}$ & $1,19 \mathrm{a}$ & $3,12 \mathrm{ab}$ & $4,57 \mathrm{a}$ \\
$\mathrm{C}$ & $4,37 \mathrm{a}$ & $1,69 \mathrm{a}$ & $2,57 \mathrm{ab}$ & $3,77 \mathrm{a}$ \\
$\mathrm{D}$ & $4,16 \mathrm{a}$ & $1,65 \mathrm{a}$ & $4,23 \mathrm{ab}$ & $3,38 \mathrm{a}$ \\
E & $3,48 \mathrm{a}$ & $8,69 \mathrm{~b}$ & $9,15 \mathrm{c}$ & $13,43 \mathrm{bc}$ \\
F & $4,65 \mathrm{a}$ & $2,22 \mathrm{a}$ & $4,22 \mathrm{ab}$ & $7,80 \mathrm{ab}$ \\
$\mathrm{G}$ & $4,29 \mathrm{a}$ & $2,04 \mathrm{a}$ & $5,04 \mathrm{~b}$ & $6,15 \mathrm{a}$ \\
$\mathrm{H}$ & $2,63 \mathrm{a}$ & $1,32 \mathrm{a}$ & $1,55 \mathrm{a}$ & $2,60 \mathrm{a}$ \\
I & $3,52 \mathrm{a}$ & $8,95 \mathrm{~b}$ & $13,94 \mathrm{~d}$ & $17,60 \mathrm{c}$ \\
J & $4,57 \mathrm{a}$ & $2,62 \mathrm{a}$ & $5,27 \mathrm{~b}$ & $9,28 \mathrm{ab}$ \\
K & $3,69 \mathrm{a}$ & $2,09 \mathrm{a}$ & $2,39 \mathrm{ab}$ & $5,43 \mathrm{a}$ \\
L & $3,12 \mathrm{a}$ & $1,82 \mathrm{a}$ & $4,78 \mathrm{ab}$ & $3,87 \mathrm{a}$ \\
\hline \hline
\end{tabular}

Keterangan : Nilai rata-rata yang diikuti oleh huruf yang sama menunjukkan tidak berbeda nyata menurut uji Duncan pada taraf 5\%
Tinggi Tanaman. Hasil analisis data terhadap tinggi tanaman pada Tabel 5 menunjukkan bahwa setiap perlakuan memberikan pengaruh yang tidak berbeda nyata terhadap tinggi tanaman padi. Hal ini dapat disebabkan karena pada tiap perlakuan unsur-unsur utama yang dibutuhkan oleh tanaman dan pada awal pertumbuhan unsur-unsur tersebut sudah tercukupi sehingga tidak terlihat perbedaan yang nyata antar perlakuan. Tinggi tanaman 2 MST sampai 8 MST tidak berbeda nyata pada setiap perlakuan dikarenakan gulma yang tumbuh tidak lebih tinggi dari tanaman padi.

Tabel 5. Pengaruh Penyiangan dan Jarak Tanam terhadap Tinggi Tanaman Padi Kultivar Ciherang pada Umur 2 MST, 4 MST, 6 MST, dan 8 MST.

\begin{tabular}{ccccc}
\hline \hline \multirow{2}{*}{ Perlakuan } & Rata-Rata Bobot Tinggi Tanaman (cm) \\
& \multicolumn{4}{c}{ pada Umur } \\
\cline { 2 - 5 } & 2 MST & 4 MST & 6 MST & 8 MST \\
\hline A & $43,80 \mathrm{a}$ & $57,33 \mathrm{a}$ & $57,93 \mathrm{a}$ & $74,83 \mathrm{a}$ \\
$\mathrm{B}$ & $46,00 \mathrm{a}$ & $59,41 \mathrm{a}$ & $62,02 \mathrm{a}$ & $76,33 \mathrm{a}$ \\
$\mathrm{C}$ & $45,33 \mathrm{a}$ & $59,25 \mathrm{a}$ & $63,72 \mathrm{a}$ & $74,75 \mathrm{a}$ \\
$\mathrm{D}$ & $46,66 \mathrm{a}$ & $60,50 \mathrm{a}$ & $63,35 \mathrm{a}$ & $74,50 \mathrm{a}$ \\
$\mathrm{E}$ & $46,26 \mathrm{a}$ & $59,83 \mathrm{a}$ & $61,29 \mathrm{a}$ & $72,50 \mathrm{a}$ \\
$\mathrm{F}$ & $47,06 \mathrm{a}$ & $59,41 \mathrm{a}$ & $60,67 \mathrm{a}$ & $72,50 \mathrm{a}$ \\
$\mathrm{G}$ & $47,20 \mathrm{a}$ & $59,08 \mathrm{a}$ & $61,13 \mathrm{a}$ & $71,25 \mathrm{a}$ \\
$\mathrm{H}$ & $49,06 \mathrm{a}$ & $61,08 \mathrm{a}$ & $66,50 \mathrm{a}$ & $73,08 \mathrm{a}$ \\
$\mathrm{I}$ & $49,66 \mathrm{a}$ & $63,91 \mathrm{a}$ & $65,12 \mathrm{a}$ & $70,58 \mathrm{a}$ \\
$\mathrm{J}$ & $49,13 \mathrm{a}$ & $63,16 \mathrm{a}$ & $64,77 \mathrm{a}$ & $74,75 \mathrm{a}$ \\
K & $48,73 \mathrm{a}$ & $60,08 \mathrm{a}$ & $62,81 \mathrm{a}$ & $75,00 \mathrm{a}$ \\
L & $49,40 \mathrm{a}$ & $61,83 \mathrm{a}$ & $64,40 \mathrm{a}$ & $73,75 \mathrm{a}$ \\
\hline \hline
\end{tabular}

Keterangan : Nilai rata-rata yang diikuti oleh huruf yang sama menunjukkan tidak berbeda nyata menurut uji Duncan pada taraf 5\%

Hal tersebut dapat terjadi karena gulma ternaungi oleh tanaman padi. Gulma yang ternaungi tidak dapat tumbuh dengan baik, karena tidak mendapat cukup sinar matahari untuk proses perkembangbiakannya. Hal ini sesuai dengan hasil penelitian Nalwida Rozen dkk, (2006) yang menyatakan bahwa tinggi tanaman padi varietas Ciherang yang dipersaingkan dengan gulma tingginya tidak sama, yaitu antara 64,83 - 80,83 cm tergantung jenis gulma yang menyainginya. Selain itu Yandianto (2003) juga menyatakan bahwa gulma akan menyerap mineral dan hara yang diperlukan oleh tanaman padi, karena hampir semua gulma golongan rumput menurut Nouriwan dan Nourizal (2004) mempunyai perakaran yang melekat kuat pada tanah dan sangat kompetitif serta sangat efisien dalam penyerapan unsur

Widayat dan Purba: Produktivitas tanaman dan kehilangan hasil tanaman padi (Oryza sativa L.)

kultivar Ciherang pada kombinasi jarak tanam dengan frekuensi penyiangan berbeda 
hara sehingga pertumbuhan tanaman padi yang berkompetisi dengan gulma akan terhambat karena gulma lebih banyak menyerap unsur hara dibandingkan dengan tanaman padi. Tinggi tanaman merupakan indikator pertumbuhan yang digunakan untuk mengukur pengaruh lingkungan atau perlakuan yang diterapkan, karena tinggi tanaman merupakan ukuran pertumbuhan yang paling mudah dilihat (Sitompul dan Guritno, 1995).

Jumlah Anakan Produktif. Hasil analisis data pada Tabel 6 menunjukkan bahwa pada umur 2 MST rata-rata jumlah anakan pada setiap perlakuan tidak berbeda nyata. Hal ini disebabkan adanya suplai hara nitrogen dari tanah yang masih mencukupi untuk pertumbuhan tanaman. Begitu juga rata-rata jumlah anakan pada umur 6 MST tidak berbeda nyata satu dengan yang lainnya, karena pada umur ini suplai unsur hara masih baik dan belum terjadi kompetisi yang terlalu besar antara tanaman padi dengan gulma. Pada umur 6 MST dan 8 MST memberikan pengaruh yang berbeda nyata terhadap jumlah anakan tanaman padi sawah kultivar Ciherang.

Tabel 6. Pengaruh Penyiangan dan Jarak Tanam terhadap Jumlah Anakan kultivar Ciherang pada umur 2 MST, 4 MST, 6 MST, dan 8 MST.

\begin{tabular}{ccccc}
\hline \hline Perlakuan & \multicolumn{4}{c}{ Rata-Rata Bobot Jumlah Anakan } \\
& \multicolumn{4}{c}{ pada Umur } \\
\cline { 2 - 5 } & 2 MST & 4 MST & 6 MST & 8 MST \\
\hline A & 13,42 a & 21,50 a & 25,58 a & $23,75 \mathrm{a}$ \\
B & 16,58 a & $30,33 \mathrm{a}$ & $28,08 \mathrm{a}$ & $26,25 \mathrm{ab}$ \\
C & $15,58 \mathrm{a}$ & $28,58 \mathrm{a}$ & $31,00 \mathrm{a}$ & $29,17 \mathrm{abc}$ \\
D & $14,75 \mathrm{a}$ & $36,67 \mathrm{a}$ & $30,67 \mathrm{a}$ & $28,83 \mathrm{bcd}$ \\
E & $15,92 \mathrm{a}$ & $26,75 \mathrm{a}$ & $24,25 \mathrm{a}$ & $22,42 \mathrm{bcd}$ \\
F & $16,92 \mathrm{a}$ & $26,67 \mathrm{a}$ & $27,08 \mathrm{a}$ & $25,17 \mathrm{~cd}$ \\
G & $15,50 \mathrm{a}$ & $23,17 \mathrm{a}$ & $29,17 \mathrm{a}$ & $27,50 \mathrm{~d}$ \\
H & $17,00 \mathrm{a}$ & $25,50 \mathrm{a}$ & $30,08 \mathrm{a}$ & $28,42 \mathrm{~d}$ \\
I & $16,58 \mathrm{a}$ & $21,83 \mathrm{a}$ & $28,25 \mathrm{a}$ & $26,58 \mathrm{~d}$ \\
J & $16,83 \mathrm{a}$ & $29,92 \mathrm{a}$ & $30,58 \mathrm{a}$ & $28,92 \mathrm{~d}$ \\
K & $17,58 \mathrm{a}$ & $28,83 \mathrm{a}$ & $32,17 \mathrm{a}$ & $34,25 \mathrm{e}$ \\
L & $16,00 \mathrm{a}$ & $30,67 \mathrm{a}$ & $34,08 \mathrm{a}$ & $33,67 \mathrm{e}$ \\
\hline \hline
\end{tabular}

Keterangan : Nilai rata-rata yang diikuti oleh huruf yang sama menunjukkan tidak berbeda nyata menurut uji Duncan pada taraf 5\%.

Pada umur 2 MST dan 4 MST rata-rata jumlah anakan tidak berbeda nyata pada setiap perlakuan disebabkan karena jarak tanam yang dipakai dalam pertanaman padi sawah cukup lebar yaitu $25 \times 25 \mathrm{~cm}, 28 \times 28 \mathrm{~cm}$, dan $30 \times 30$ $\mathrm{cm}$, dan pada umur ini, tanaman padi belum tumbuh sempurna, sehingga apabila ada gulma tidak mempengaruhi jumlah anakan. Ruang tumbuh yang cukup luas menyebabkan persaingan antara tanaman padi dan gulma masih leluasa untuk tumbuh dan menyerap unsur hara yang dibutuhkan tanaman. Sejalan dengan itu daun yang berada di atas tanah masih bebas untuk menyerap cahaya matahari guna keperluan fotosintesis, sehingga tanaman padi masih dapat tumbuh dengan baik, hal ini berakibat rata-rata jumlah total anakan tiap rumpun yang dihasilkan pada perlakuan tidak berbeda nyata.

Pada pertumbuhan awal tanaman padi, adanya gulma dalam jumlah yang sedikit tidak akan dapat menurnkan hasil panen. Menurut Sastroutomo (1990), jenis tanaman yang lambat menguasai lahan tempat tumbuhnya akan mengakibatkan gulma dapat tumbuh lebih cepat dan menyebabkan kematian bagi tanaman pokok. Oleh karena itu, pada jenis tanaman budidaya yang penguasaan ruangnya lambat, kompetisi dapat terjadi sejak awal pertumbuhannya.

Tabel 7. Pengaruh Penyiangan dan Jarak Tanam terhadap BobotKering Tanaman Padi kultivar Ciherang pada umur 2 MST, 4 MST, 6 MST, dan 8 MST.

\begin{tabular}{ccccc}
\hline \hline Perlakuan & \multicolumn{4}{c}{ Rata-Rata Bobot Kering Tanaman } \\
& \multicolumn{4}{c}{ Padi pada Umur } \\
\cline { 2 - 5 } & 2 MST & 4 MST & 6 MST & 8 MST \\
\hline A & $16,25 \mathrm{a}$ & $43,82 \mathrm{a}$ & $91,59 \mathrm{a}$ & $144,40 \mathrm{a}$ \\
B & $19,67 \mathrm{a}$ & $53,12 \mathrm{a}$ & $111,03 \mathrm{a}$ & $175,29 \mathrm{a}$ \\
C & $22,12 \mathrm{a}$ & $60,73 \mathrm{a}$ & $126,93 \mathrm{a}$ & $141,11 \mathrm{a}$ \\
D & $21,61 \mathrm{a}$ & $59,47 \mathrm{a}$ & $124,29 \mathrm{a}$ & $186,12 \mathrm{a}$ \\
E & $21,64 \mathrm{a}$ & $56,22 \mathrm{a}$ & $117,51 \mathrm{a}$ & $132,90 \mathrm{a}$ \\
F & $20,16 \mathrm{a}$ & $47,34 \mathrm{a}$ & $108,72 \mathrm{a}$ & $158,88 \mathrm{a}$ \\
G & $17,13 \mathrm{a}$ & $47,18 \mathrm{a}$ & $90,08 \mathrm{a}$ & $160,12 \mathrm{a}$ \\
H & $18,40 \mathrm{a}$ & $43,29 \mathrm{a}$ & $109,67 \mathrm{a}$ & $135,29 \mathrm{a}$ \\
I & $21,54 \mathrm{a}$ & $53,70 \mathrm{a}$ & $106,05 \mathrm{a}$ & $167,25 \mathrm{a}$ \\
J & $30,99 \mathrm{a}$ & $65,97 \mathrm{a}$ & $138,57 \mathrm{a}$ & $162,25 \mathrm{a}$ \\
K & $16,09 \mathrm{a}$ & $44,01 \mathrm{a}$ & $88,49 \mathrm{a}$ & $141,37 \mathrm{a}$ \\
L & $17,49 \mathrm{a}$ & $46,71 \mathrm{a}$ & $120,45 \mathrm{a}$ & $147,82 \mathrm{a}$ \\
\hline \hline
\end{tabular}

Keterangan : Nilai rata-rata yang diikuti oleh huruf yang sama menunjukkan tidak berbeda nyata menurut uji Duncan pada taraf 5\%

Bobot kering Tanaman. Dari Tabel 7 menunjukkan bahwa tidak ada perbedaan nyata antar perlakuan terhadap bobot kering tanaman. Hal ini dikarenakan pada setiap perlakuan gulma sudah dapat diatasi. Walau tanpa penyiangan dan jarak tanam yang kecil ataupun tidak optimal, 
gulma tidak begitu mempengaruhi bobot kering tanaman padi tersebut dikarenakan tanaman dan gulma sudah dapat memenuhi akan kebutuhan hara yang masing-masing.

Komponen Hasil Tanaman Padi. Perlakuan yang paling menghasilkan jumlah malai per rumpun yang paling baik adalah perlakuan $\mathrm{L}$ dengan penyiangan tiga kali dan jarak tanam paling lebar diantara perlakuan lainnya. Hal ini memungkinkan tingkat persaingan gulma dan tanaman sangat rendah, sehingga tanaman dapat menghasilkan jumlah malai yang baik. Demikian sebaliknya, jumlah malai yang paling sedikit dihasilkan ditunjukkan oleh perlakuan A, karena pengaruh tanpa penyiangan dan jarak tanam yang paling kecil diantara perlakuan lainnya.

Tabel 8. Komponen Hasil Tanaman Padi Kultivar Ciherang Yang Diberi Perlakuan Jarak Tanam dan Penyiangan Yang Berbeda.

\begin{tabular}{|c|c|c|c|c|}
\hline Perlakuan & $\begin{array}{l}\text { Jumlah } \\
\text { Malai Per } \\
\text { Rumpun }\end{array}$ & $\begin{array}{l}\text { Jumlah } \\
\text { Bobot } \\
\text { Kering Per } \\
\text { Rumpun } \\
\text { (g) }\end{array}$ & $\begin{array}{c}\text { Jumlah } \\
\text { Bobot } \\
1000 \\
\text { Butir } \\
\text { (g) }\end{array}$ & $\begin{array}{c}\text { Jumlah } \\
\text { Bobot } \\
\text { Bernas } \\
(\%)\end{array}$ \\
\hline A & 17,33 a & $51,18 \mathrm{a}$ & $25,387 \mathrm{a}$ & $78,00 \mathrm{a}$ \\
\hline B & $20,06 \mathrm{ab}$ & $53,64 \mathrm{ab}$ & $27,664 \mathrm{a}$ & $78,20 \mathrm{a}$ \\
\hline $\mathrm{C}$ & 21,06 bc & $56,61 \mathrm{abc}$ & $25,868 \mathrm{a}$ & $80,50 \mathrm{a}$ \\
\hline D & $22,33 \mathrm{bcd}$ & 57,08 abc & $25,72 \mathrm{a}$ & $81,20 \mathrm{a}$ \\
\hline $\mathrm{E}$ & $20,20 \mathrm{ab}$ & $56,94 \mathrm{abc}$ & $25,851 \mathrm{a}$ & $83,80 \mathrm{~b}$ \\
\hline $\mathrm{F}$ & 23,00 bcde & 57,76 bc & 27,218 a & $76,90 \mathrm{a}$ \\
\hline G & 23,76 cde & $61,54 \mathrm{c}$ & $27,102 \mathrm{a}$ & $74,90 \mathrm{a}$ \\
\hline $\mathrm{H}$ & 23,30 bcde & $60,12 b c$ & 26,161 a & $78,70 \mathrm{a}$ \\
\hline I & $21,30 \mathrm{bc}$ & $62,43 \mathrm{~cd}$ & $27,432 \mathrm{a}$ & $89,80 \mathrm{~b}$ \\
\hline $\mathrm{J}$ & 24,63 de & $68,14 \mathrm{~d}$ & 28,419 a & $79,80 \mathrm{a}$ \\
\hline K & 26,06 ef & $75,05 \mathrm{e}$ & 26,481 a & $79,50 \mathrm{a}$ \\
\hline L & $28,06 \mathrm{f}$ & $82,25 \mathrm{f}$ & $26,558 \mathrm{a}$ & $89,90 \mathrm{~b}$ \\
\hline
\end{tabular}

Keterangan : Nilai rata-rata yang diikuti oleh huruf yang sama menunjukkan tidak berbeda nyata menurut uji Duncan pada taraf 5\%

Bobot 1000 butir gabah kultivar Ciherang berdasarkan deskripsi adalah $28 \mathrm{~g}$ (Badan Penelitian dan Pengembangan Pertanian, 2010). Tabel 8 menunjukkan hasil bobot 1000 butir yang baik, karena memenuhi syarat dari deskripsi varietas padi Ciherang tersebut.

Jumlah bobot kering gabah per rumpun juga dapat dilihat pada Tabel 8 bahwa dengan perlakuan jarak tanam $25 \times 25 \mathrm{~cm}$ tanpa penyiangan menghasilkan jumlah gabah yang sedikit dibanding dengan perlakuan jarak tanam
$30 \times 30 \mathrm{~cm}$ dengan penyiangan maksimal atau tiga kali penyiangan. Adapun antar perlakuan lain memberikan pengaruh yang berbeda sedikit satu dengan yang lain dikarenakan hasil kompetisi yang terjadi antara tanaman padi dengan gulma. Tetapi tidak begitu memberikan pengaruh perbedaan yang nyata terhadap hasil jumlah bobot gabah kering per rumpun.

Hasil tanaman padi ditentukan oleh jumlah malai pertanaman atau per satuan luas, kepadatan malai, gabah bernas, dan berat 1000 butir. Umumnya jumlah malai pertanaman ditentukan fase vegetatif, kepadatan malai, gabah isi dan berat 1000 butir pertanaman ditentukan pada fase pemasakan.Faktor-faktor kesuburan tanah dan jarak tanam juga mempengaruhi jumlah anakan yang menghasilkan malai. Jumlah gabah permalai tergantung kegiatan fotosintesi tanaman selama fase reproduktif. Kondisi tanaman yang baik akan memaksimalkan proses pengisian bulir melalui kecukupan hara, cahaya, dan air, hal tersebut ditunjang oleh pendapat Cassanova (2002) yang menyatakan bahwa periode pertumbuhan tanaman pada stadia pengisian bulir sangat menentukan hasil akhir dan temperatur sangat berperan penting dalam hal ini, karena menurut Takai dkk., (2006) tingginya radiasi surya selama periode pengisian bulir dapat meningkatkan produksi biomass yang berakibat terhadap tingginya bulir yang masak yang selanjutnya akan meningkatkan hasil tanaman padi

Pengamatan Hasil Tanaman Padi dan Kehilangan Hasil. Dari Tabel 9 dapat dilihat bahwa setiap perlakuan yang berbeda memberikan pengaruh yang berbeda terhadap hasil panen tanaman padi. Hasil yang tertinggi tetap terjadi pada perlakuan L yaitu penyiangan tiga kali dengan jarak tanam paling lebar yaitu $30 \mathrm{x}$ $30 \mathrm{~cm}$. Jarak tanam yang lebar memungkinkan persaingan antara gulma dengan tanaman itu sedikit, sehingga tanaman dapat mengambil unsur hara untuk mencukupi kebutuhannya.

Hasil gabah panen per ton padi kultivar Ciherang berdasarkan deskripsi adalah 6 ton/ha dan memiliki potensi hasil sebesar 8,5 ton/ha. Berdasarkan percobaan yang dilakukan hasil tertinggi diperoleh $\pm 6,28$ ton/ha. Dalam hal ini, hasil percobaan memiliki nilai yang baik, dan hasilnya tidak jauh berbeda dengan deskripsi tanaman padi tersebut.

Widayat dan Purba: Produktivitas tanaman dan kehilangan hasil tanaman padi (Oryza sativa L.) 
Tabel 9. Pengaruh Perlakuan terhadap Hasil Gabah Kering Panen Per Petak (kg) dan Per Hektar (ton) Tanaman Padi Sawah Kultivar Ciherang

\begin{tabular}{cccc}
\hline \hline Perlakuan & $\begin{array}{c}\text { Hasil Gabah } \\
\text { Panen (g/petak) }\end{array}$ & $\begin{array}{c}\text { Hasil } \\
\text { Gabah } \\
\text { Panen } \\
\text { (ton/ha) }\end{array}$ & $\begin{array}{c}\text { Kehilangan } \\
\text { Hasil (\%) }\end{array}$ \\
\hline A & $26184,83 \mathrm{~b}$ & 5,23 & $-15,4$ \\
$\mathrm{~B}$ & $30086,21 \mathrm{~cd}$ & 6,01 & $-2,8$ \\
$\mathrm{C}$ & $31304,66 \mathrm{~d}$ & 6,26 & 1,14 \\
$\mathrm{D}$ & $30952,53 \mathrm{~d}$ & 6,19 & 0 \\
E & $24068,78 \mathrm{ab}$ & 4,81 & $-22,24$ \\
F & $25151,46 \mathrm{ab}$ & 5,03 & $-18,74$ \\
$\mathrm{G}$ & $27050,67 \mathrm{bc}$ & 5,41 & $-12,61$ \\
$\mathrm{H}$ & $25653,53 \mathrm{~b}$ & 5,13 & $-17,12$ \\
I & $21636,79 \mathrm{a}$ & 4,32 & $-30,1$ \\
J & $27025,01 \mathrm{bc}$ & 5,4 & $-12,69$ \\
K & $27745,72 \mathrm{bc}$ & 5,54 & $-10,36$ \\
L & $31414,36 \mathrm{~d}$ & 6,28 & 1,49 \\
\hline \hline
\end{tabular}

Keterangan : Nilai rata-rata yang diikuti oleh huruf yang sama menunjukkan tidak berbeda nyata menurut uji Duncan pada taraf 5\%

Tanaman padiumumnya ditanam dengan jarak tanam standar yaitu $25 \times 25 \mathrm{~cm}$. Jarak tanam ini dijadikan sebagai kontrol untuk melihat kehilangan hasil yang terjadi pada setiap perlakuan. Pada penelitian ini, perlakuan D dijadikan sebagai kontrol, dimana perlakuan D tersebut adalah perlakuan dengan jarak tanam $25 \times 25 \mathrm{~cm}$ dengan disiang tiga kali. Setiap perlakuan dibandingkan dengan perlakuan ini, sehingga dapat dilihat apakah terjadi kehilangan hasil atau tidak. Hasil perbandingan memperlihatkan bahwa hanya perlakuan C (jarak tanam $25 \times 25 \mathrm{~cm}$ dengan disiang tiga kali) dan perlakuan L (jarak tanam $30 \times 30 \mathrm{~cm}$ dengan disiang 3 kali) kehilangan hasilnya kurang dari 3 $\%$. Kehilangan hasil tertinggi didapatkan pada perlakuan jarak tanam $30 \times 30 \mathrm{~cm}$ dengan tanpa penyiangan dan perlakuan jarak tanam $28 \times 28$ $\mathrm{cm}$ dengan tanapa penyiangan. Hal ini bisa difahami karena dengan jarak tanam yang agak lebar maka gulma akan tumbuh dengan leluasa, sehingga jika tidak dilakukan penyiangan maka kompetisi yang terjadi akan semakin tinggi dan akan menyebabkan kehilangan hasil tanaman padi menjadi tinggi.

\section{Kesimpulan dan Saran}

\section{Kesimpulan}

1. Jarak tanam dan frekuensi penyiangan berpengaruh terhadap penekanan gulma, produktivitas dan kehilangan hasil padi sawah kultivar Ciherang.

2. Jarak tanam $30 \times 30 \mathrm{~cm}$ dengan penyiangan tiga kali mampu memberikan produktivitas yang tinggi yaitu 6,28 ton/ha dan meningkatkan hasil sebesar 1,49\% dibandingkan dengan jarak tanam standar, yaitu $25 \times 25$ $\mathrm{cm}$ dengan tiga kali penyiangan.

3. Kehilangan hasil yang tinggi yaitu sebesar $30,1 \%$ diperoleh dari perlakuan jarak tanam $30 \times 30 \mathrm{~cm}$ dengan tanpa penyiangan.

\section{Saran}

Berdasarkan hasil penelitian, pembahasan serta kesimpulan maka disarankan :

a. Perlakuan yang paling baik untuk mendapatkan hasil yang tinggi ialah menanam tanaman padi dengan jarak $30 \times 30 \mathrm{~cm}$ dengan frekuensi penyiangan tiga kali.

b. Untuk memantapkan penelitian ini, diharapkan dilakukan penelitian selanjutnya yaitu produktivitas tanaman padi pada jarak tanam dengan pengendalian gulma menggunakan herbisida.

\section{Daftar Pustaka}

Aldrich, R.J. 1984. Weed Crop Ecology. Principles in Weed Management. Breton Publisher, a Division of Wadsworth, Inc. North Scituate, Massachusetts

Anderson, P.W.. 1997. Weed Science Principles, West Publishing Co. USA

Badan Penelitian dan Pengembangan Pertanian Pusat Penelitian dan Pengembangan Tanaman Pangan Balai Penelitian Tanaman Padi. 2010. Deskripsi Varietas Unggul Padi dan Palawija

Beurlin, J.E., 1971. Effect of Branch Removal and Light Use Efficiency of Soybean Canopies. Agron

Cassanova, D.J.Gourdian.,M.M.C. Former and J.C.M. Withangen. 2002. Rice yield prediction from yield component and limiting factors. Europe. J. Agronomy 17 :41-61 
Christin Juliana. 2010. Persaingan antara Tanaman dan Gulma.

Madkar, O.R, S. Mangunsoekarjo, T. Kontohartono, 1986. Gulma dan Cara Pengendaliannya.

Nasution, U, 1968. Gulma dan Pengendaliannya di Sumatera Utara dan Aceh. Pusat Penelitian dan Pengembangan Perkebunan Tanjung Merawa, Sumatera Utara.

Nalwida Rozen, Musliar Kasim, dan Irfan Suliansyah. 2006. Pengujian tingkat toleransi kultivar padi sawah terhadap gulma. Jurnal Akta Agrosia. Vol.9 No 2, hlm 86-93. JuliDesember 2006. http; / / www.bdpinib.org /akta/qrtike; akta/86.pdf

Sitompul, S.M. dan B. Guritno. 1995. Analisis Pertumbuhan Tanaman. Gajah Mada Univercity Press. Yogyakarta. P:94.

Spitter, C.J.T dan Van der Berg. 1982. Competition Between Crop and Weed:A System Apreoche. P: 137-148. in W. Hozner (ed). Biology and Ecology of Weeds. D.W. Jumh Publishers. The Huque, Boston: London.

Takai, T., S. Matsura, T. Nishio, A. Ohsumi, T. Shiralwa and T. Horie. 2006. Rice yield potential is closly realted to crop growth rate during late reproductive period. Field Crop Res. 96: 328-329 